\title{
SOLVING WINDOWS 7 COMPATIBILITY PROBLEMS, THE WAY TO VIRTUALIZATION
}

\section{Josef HORÁLEK-Petr $\check{S} U B A$}

\begin{abstract}
This article deals with possibilities to solve compatibility programs which are created for previous versions of Microsoft operating system. It presents and explains possibilities of solving via original complements in Microsoft Windows 7. The accent is posed on eduacional software and to design optimal solutions of compatibility problems.
\end{abstract}

Key words: virtualization, compatability, XP MOD.

\section{OD ŘEŠENÍ PROBLÉMŮ S KOMPATIBILITOU VE WINDOWS 7 PO VIRTUALIZACI}

Resumé: Článek se zabývá možnostmi řešení kompatibility programů vytvořených pro předchozí verze operačního systému Microsoft. Představuje a vysvětluje možnosti jejich řešeni pomoci originálnich doplňkư v Microsoft Windows 7. Důraz je kladen na edukačni software a navrženi optimálního řešení problémů kompatibility.

Klíčová slova: virtualizace, kompatibilita, XP MOD.

\section{1 Úvod}

Za posledních několik let prošly operační systémy od firmy Microsoft, které jsou stále nejrozšířenějšími, významným vývojem. Po několikaleté stagnaci nastal dynamický vývoj, odstartovaný nástupem operačního systému Windows Vista. Po necelých dvou letech přišel jeho nástupce Windows 7 , později i s novým jádrem označovaným R2. Tento vývoj má za následek, že mnoho uživatelských programů, vyvíjených pro platformu Windows XP a starší, se na moderních operačních systémech potýká s nemalými problémy. Tyto potíže se z velké části týkají i, u nás rozšířených, edukačních materiálů, jejichž vývoj často zaostává za vývojem $\mathrm{v}$ oblasti operačních systémů [1]. Nemalou roli hraje i jejich finanční stránka. $\mathrm{Z}$ těchto důvodů a ze zkušeností autorů budou představeny možnosti řešení této problematiky $\mathrm{s}$ přihlédnutím $\mathrm{k}$ principům funkce navrhovaných řešení. V článku je čerpáno ze zkušeností získaných při výuce i ve výzkumu.

Pro řešení zmíněných problémů $\mathrm{v}$ obecné rovině není možno omezit výběr pouze na jednu použitelnou technologii. Přestože lze obhájit tvrzení, že existuje univerzální řešení využivající vizualizačních technologií.

$\mathrm{K}$ úspěchu často postačuje využití podstatně jednodušších prístupů $\mathrm{s}$ menšími nároky na dovednosti i použité technologie.

Nejjednodušší možností je využití integrované funkce operačního systému pro vyhledání řešení ze zdrojů poskytovaných znalostní databází výrobce operačního systému. Tato možnost je v článku zmíněna včetně představení jeho využití a funkce.

Sofistikovanější možností je využití integrované podpory česky nazývané režim kompatibility, který lze považovat $\mathrm{v}$ některých př́ípadech za řešení možných potíží.

Poslední představenou cestou $\mathrm{k}$ cíli je využití technologie virtualizace operačního systému s důrazem na minimalizaci nákladů, zachování uživatelského komfortu a jednoduchosti obsluhy.

\section{Problém kompatibility}

$\mathrm{V}$ převážné většině originálních materiálů od tvůrců operačního systému Windows 7 např. [2], [3] a [4], lze nalézt tvrzení o bezproblémovém chodu většiny aplikací vytvořených pro starší verze operačních systémů od firmy Microsoft. Vlastní zkušenosti autorů však ukazují, že při běžném používání operačního systému Windows $7, \mathrm{v}$ didaktickém prostředí se problémy s kompatibilitou vyskytují relativně často. Při pokusu nainstalovat, nebo spustit, v tomto smyslu problémovou, aplikaci operační systém zareaguje systémovým hlášením (Obr. 1). Automaticky jsou nabízeny tři možnosti řešení, za kterými se ovšem skrývá několik kroků, které operační systém vykoná, aniž by si je běžný uživatel mohl uvědomit. Toto logicky neplatí pro poslední volbu, kterou je stornování požadavku. 


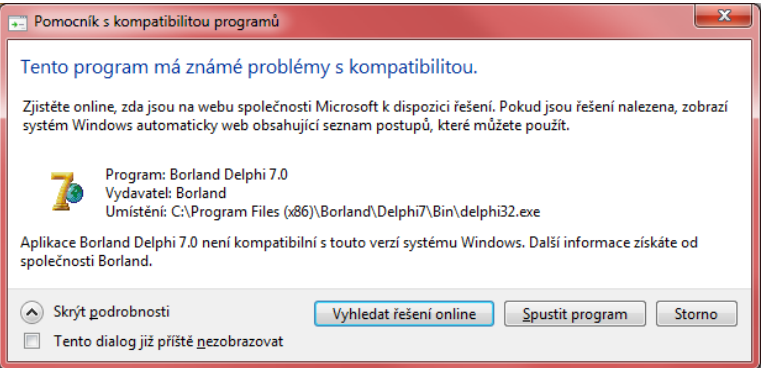

(Obr 1: Upozornění systému Windows na problémy s kompatibilitou)

Je-li vybrána volba spustit program, i přes uvedené upozornění na problémy s kompatibilitou, nelze zaručit spolehlivý a úplný běh dané aplikace, případně ani její korektní instalaci. Casto se lze setkat se situací, kdy instalace proběhla bez dalších informací, ale nainstalovanou aplikaci nelze spustit. Za tímto jevem se může skrývat několik příčin se stejným výsledným projevem. Na operačních systémech z produkce firmy Microsoft platí, že každá instalace více či méně ovlivňuje samotný operační systém. Proto většina moderních aplikací (instalovaných standardním postupem) dává operačnímu systému automaticky požadavek na vytvoření bodu obnovení systému. Tuto bezpečností pojistku však aplikace vyvinuté pro starší verze operačního systému nemaji a jejich instalací tak lze negativně a nenávratně ovlivnit stav samotného operačního systému.

Pod pojmem bod obnovení systému je v pojetí tvůrců operačních systémů Windows chápáno vytvoření částečné zálohy klíčových součástí operačního systému, neboli snímku aktuálního stavu.

Pokud zastaralý instalační proces bod obnovy nenabízí a operační systém uživatele uvedeným způsobem varuje, je vhodné bod obnovení vytvořit s využitím integrovaného průvodce.

Ani vyžádané vytvoření bodu obnovení bohužel negarantuje spolehlivou možnost se vrátit zpět $\mathrm{k}$ původnímu stavu systému. Důvodem je, že aplikace instalovaná dnes již zastaralými způsoby může porušovat doporučené prístupy $\mathrm{k}$ využívání možností operačního systému.

\section{Vyhledání řešení ve znalostní bázi}

Tvưrci operačního sytému vyhověli četným požadavkům na technickou podporu a integrovali do rozhraní systému možnost využívání již zpracovaných postupů řešení opakovaně se vyskytujících problémů. Jak je zrejmé, operační systém se pokusí nalézt online řešení bez zásahů uživatele $\mathrm{s}$ využitím dostupných informací.
Za tímto, navenek jasným a jednoduchým, postupem se skrývá několik dílčích činností. V prvním kroku operační systém hledá identifikátor výrobce a odkazuje na podporu, jelikož vývojáři předpokládají update aplikací pro nové verze operačních systémů. Zároveň se však spouští algoritmus hledání řešení, které nabídne jako možnost dalšího postupu.

Pokud je tímto způsobem nalezeno odpovídající řešení, operační systém generuje opravu části nekompatibilního kódu, který byl zachycen voláním API ze samotné aplikace tak, aby daná aplikace plnila stejnou funkčnost jako pro předchozí verze operačního systému [3], [6]. Pod tímto obecným tvrzením se skrývá několik možností od blokování nových funkcí Windows 7, které aplikace nepodporuje či s nimi nedokáže pracovat až po emulaci chování nižší verze operačního systému (např. ve verzi Win32 API set). Než je oprava zanesena jako nový záznam do lokální databáze oprav jako soubor *.sdb, jsou vytvořeny zprávy o blokování, označované jako AppHelp. Vytvořený soubor pak obsahuje všechny opravy a zprávy. Operační systém se pak aplikaci pokusí spustit s přidanými opravami, které testuje, a jsou li testy úspěšné, ukládá celý balíček oprav $\mathrm{v}$ podobě souboru * ${ }^{*}$.sdb do databáze, odkud je volán vždy při dalším spouštění dané aplikace [3], [4].

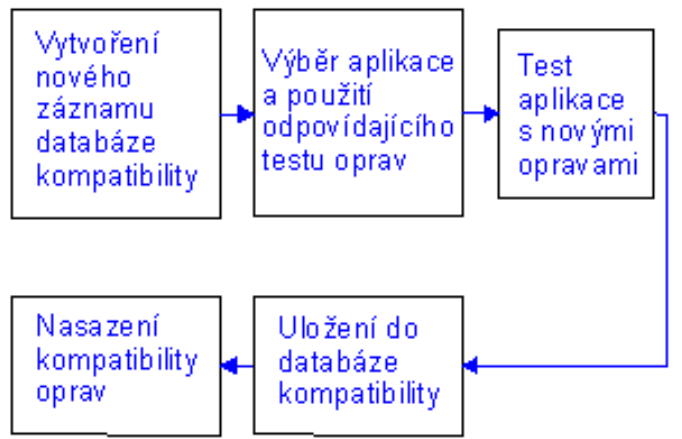

(Obr 2: Blokové schéma použití režimu kompatibility)

Aby výše popsaný proces vedl $\mathrm{k}$ úspěšnému spuštění, vyžaduje úzkou kooperaci mezi autory aplikací a firmou Microsoft, což hlavně $\mathrm{u}$ výukových programů není $\mathrm{v}$ našem prostředí zvykem. Často vlastník licence může přijít o možnost používání starších programů [1]. Proto je nasnadě zvážit využití dalších možností, které přes svou snadnou dostupnost nejsou běžně užívány.

\section{Režim kompatibility}

Často doporučovanou možností řešení problémů s kompatibilitou je změna vlastností 
zástupce daného programu. Tuto metodu je vhodné použít, proběhla-li instalace na Windows 7 korektně, ale aplikace se nechová očekávaným způsobem jako $\mathrm{v}$ předchozí verzi operačního systému. Tato možnost řešení je založena na možnosti ovlivnit vlastnosti spuštění programu, reprezentovaného zástupcem, předanými parametry spuštění. Podrobnější informace lze nalézt $\mathrm{v}$ [3]. K možnosti změnit vlastnosti vybraného zástupce programu se lze dostat kliknutím na zástupce pravým tlačítkem myši a vybráním položky VLASTNOSTI (Obr. 3), kde lze zvolit záložku „Kompatibilita“.

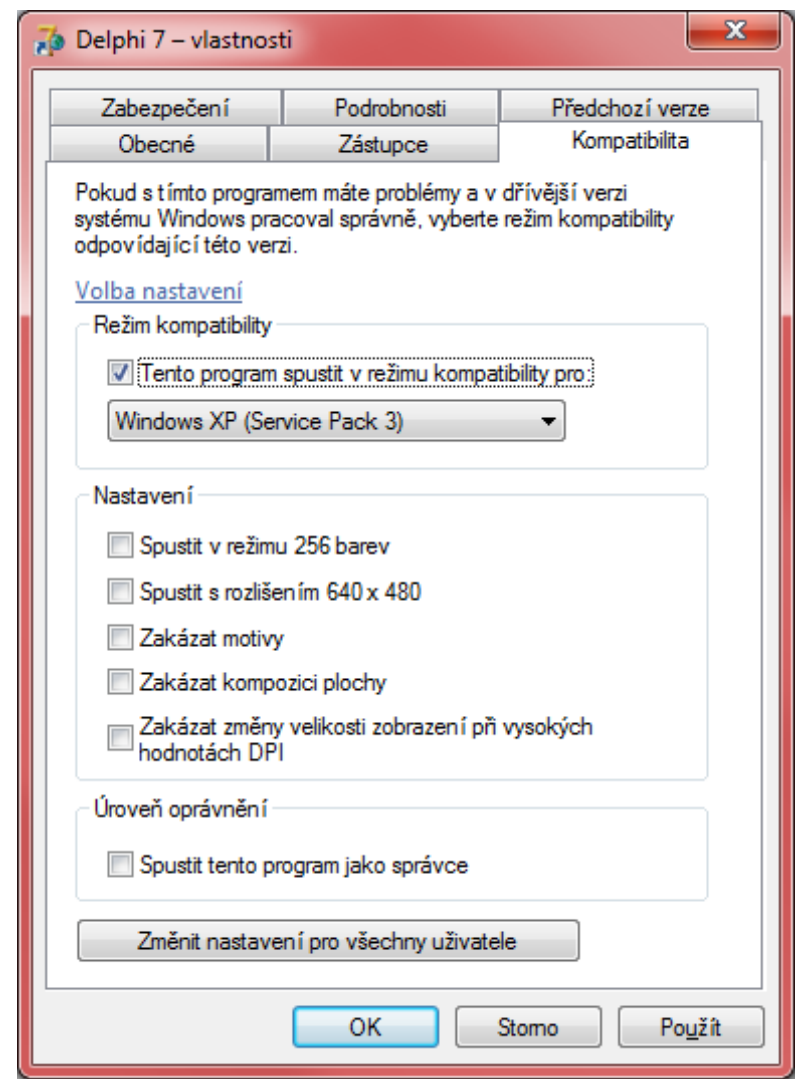

(Obr 3: Vlastnosti zástupce - záložka Kompatibilita)

Zde operační systém Windows 7 nabízí možnost spustit daný program v režimu kompatibility. Z rolovacího menu je vhodné vybrat poslední verzi operačního systému, ve kterém daný program korektně pracoval. Pokud je volba kompatibility neaktivní (zašedlá), je spouštěná aplikace 64bitová a není možno uvažovat využití režimu kompatibility. V prostřední části okna, pak lze upřesnit další parametry pro spouštění dané aplikace. Možnost spouštět program v režimu 256 barev slouží pro programy, které více barev nepodporují. Další možností je omezit rozlišení, ve kterém se daný program spouští. Tato volba řeší problémy s grafickým vzhledem aplikace, určené typicky pro straší verze OS. Zakázání motivů, je primárně určeno pro řešení vzácných problémů, s nabídkovými menu v horní liště programu (např. FoxPro). Zakázání kompozice plochy je další variantou řešení vzhledu rozhraní aplikací za jinak normálního běhu. Poslední volba umožní zakázat změnu velikosti okna aplikace za běhu. Ve spodní části pak lze povolit spouštění dané aplikace jako správce, což většina starších aplikací vyžaduje (bezpečnostní rizika jsou nad rámec tohoto článku). Pokud zvolená kombinace nastavení kompatibility vyřešila problémy, je vhodné dodatečně zapnout volbu Změnit nastavení pro všechny uživatele. Toto elegantní a jednoduché řešení má svá omezení. Jedná se o řešení, které efektivně vyřeší problémy s grafickým rozhraním.

Výše uvedené řešení je použitelné a autoři jej využili při řešení problémů s aplikačním software na střední škole, kde vyučují a spravují počítačovou sít'. Tato metoda byla úspěšně využita při řešení dvou problémů $\mathrm{s}$ výukovým software. V prvním prípadě, se jednalo o upravení zobrazování pomocí režimu kompatibility, a to pro video záznamy fyzikálních pokusů. $\mathrm{V}$ druhém případě byl režim kompatibility využit pro vyladění optimálního běhu programu na podporu výuky jazyků.

Pokud je instalace programu nekorektní či nemožná, nebo přetrvávají problémy s nekorektním během aplikace, je třeba zvolit jiný př́stup $\mathrm{k}$ řešení. Právě u elektronických výukových materiálů, dokonce i v celých e-learningových modulech není tato situace ojedinělá. Ale i zde existuje efektivní a jednoduché řešení.

\section{Windows XP Mode}

Řešením, které efektivně řeší přetrvávající problémy s kompatibilitou je využití virtualizace s nasazením Windows XP Mode. Toto řešení má však omezení $\mathrm{V}$ edicích operačního systému Windows 7. Bez dodatečného řešení licence, lze integraci operačního systému Windows XP do Windows 7 použít jen u edic Professional, Enterprise a Ultimate. $\mathrm{V}$ rámci těchto edic se jedná o volně stažitelné rozšíření systému Windows 7 o licencovanou kopii systému Windows XP SP3.

Z hlediska použité technologie se jedná o využití plné virtualizace $\mathrm{s}$ bitovou kopií Windows XP SP3 realizovaného prostřednictvím vizualizačního nástroje Windows Virtual PC. Obecné možnosti nasazení produktu Virtual PC 
ve výuce, již byli popsány v [7], a proto zde bude věnována pozornost jen využití Windows Virtual $\mathrm{PC}$, pro řešení problémů $\mathrm{s}$ kompatibilitou. Základním cílem nasazení tohoto nástroje, je paralelní chod více operačních systémů na jednom počítači, a možnost plynulého přechodu mezi nimi bez nutnosti restartování stroje. Ještě počátkem roku 2010 bylo toto řešení omezeno hardwarovou podporou virtualizace. Přibližně v polovině roku 2010 nabídla firma Microsoft update k Windows XP Mode, který umožňuje využít tento nástroj i na hardware, který primární podporu virtualizace nemá. Aby bylo možno tento nástroj používat, je nutné jej nejdřive nainstalovat. Windows Virtual PC je volně stažitelný na stránce w7io.com/0502. Po instalaci Windows Virtual PC je nutné, ze stejné stránky, stáhnout samotný Windows XP MODE, př́padně Windows XP MODE update. Windows XP MODE se po ověření legálnosti hostitelského operačního systému automaticky implementuje do Windows Virtual PC. Windows XP MODE je po restartování systému dostupný $\mathrm{v}$ následující cestě: Start - Všechny programy - Windows Virtual PC - Windows XP MODE. Samotný Windows Virtual PC je automaticky uložen v C:IUsers $\mid<$ uživatel $>\mid$ Virtual Machines. V tomto adresáři je také uložena kopie virtuálního disku WindowsXPMode.vhd.

Před spuštěním je možné nastavit vybrané vlastnosti virtuálního počítače, a to jednoduchým výběrem nabídky Nastavení z hlavního menu, které je dostupné kliknutím pravým tlačítkem myši na daný soubor. Po spuštění souboru WindowsXPMode.vhd se spustí virtuální počítač s licencovanou verzí Windows XP SP3. Tento systém má přidělený virtuální disk, který je součástí souboru WindowsXPMode.vhd. Windows Virtual PC je automaticky nastaven tak, že sdílí optické mechaniky a lze jej tedy plně využívat, stejně jako na hostitelském operačním systému. Obdobně funguje i propojení a komunikace $s$ výměnnými disky, a dalšími zařízeními připojenými přes USB. Po té co je např. externí disk připraven na hostitelském operačním systému, je nainstalován i ve virtuálním prostředí, stejně jako při běžné práci ve Windows XP. Další možností pro sdílení dat s hostitelským operačním systémem je plný př́stup na jeho logické disky. Při otevření zástupce Tento počítač, je v seznamu př́stupných jednotek definován oddíl Jiný, kde jsou př́stupné všechny disky, včetně virtuálních mechanik. Adresovány jsou pak jako disk $\mathrm{X}$ v NázevPočítače. S těmito disky se pak pracuje $\mathrm{v}$ obdobném režimu jako při využití vzdálené plochy. Z toho plyne jedno z mála omezení, které toto řešení obsahuje. Některé programy totiž není možné instalovat v režimu vzdálené plochy a tak je nutné instalaci nejprve nahrát na disk virtuálního počítače, nebo ji spouštět přes pamět'ové zařízení v rozhraní USB resp. optickou mechaniku. Práce s virtuálním počítačem je srovnatelně jednoduchá jako s fyzickým strojem a je uživatelsky vysoce komfortní. Virtuální stroj je z pohledu uživatelského rozhraní jedno vyhrazené okno na ploše hostitelského stroje, obsahující vlastní plochu, vlastní tlačítko Start i ostatní obvyklé prvky. Všechny programy nainstalované ve Widows Virtual PC jsou dostupné z hostitelského systému přes Start Všechny programy - Widows Virtual PC Aplikace prostředí Windows XP MODE, což uživatelský komfort zvyšuje a zjednodušuje obsluhu (Obr.4).

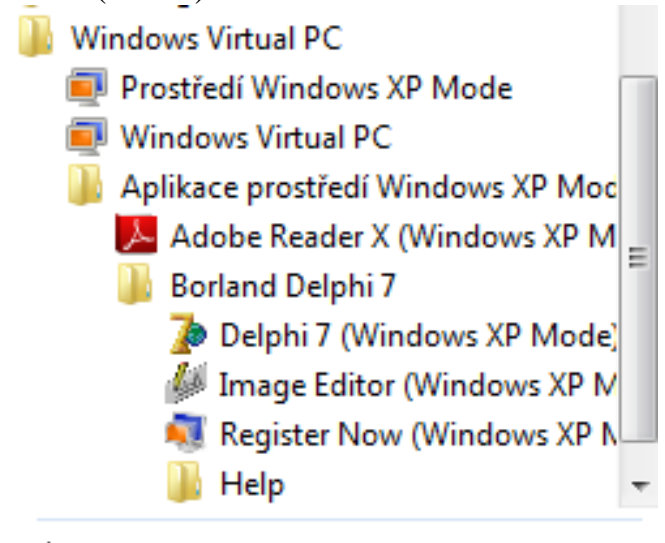

1 Zpět

Prohledat programy a soubory

(Obr 4: Aplikace prostředi Windows XP $M O D E)$

Stačí tedy danou aplikaci spustit, hostitelský operační systém na pozadí automaticky spustí proces Virtual PC (vpc.exe), ve kterém běží vlákno spouštěného programu. $V$ př́ípadě, že je program běžící ve virtuálním stroji spuštěn takto přímo z hostitelského systému, uživatel vidí pouze požadovanou aplikaci (její grafické rozhraní) a nikoli celý virtuální systém, který ovšem na pozadí ve skutečnosti běží.

Je zřejmé, že virtuální počítač potřebuje pro svoji činnost část systémových prostředků, a určitý čas pro svůj rozběh. Autoři si dovolují na základě svých zkušeností tvrdit, že nárůst vytížení procesoru není při běžném nasazení pro didaktické účely větší než $+10 \%$. Pamětová náročnost obvykle nepřesahuje 512MB 
na virtuální stroj. Lze tedy konstatovat, že na běžném moderním stolním počítači lze tento př́stup využít s dostatečnou výkonovou rezervou a ještě pozorovat určitý nárůst rychlosti odezvy zatíženého systému oproti starším strojům, na kterých programy nativně běžely v minulosti. Is touto metodou mají autoři dlouhodobou zkušenost. Prakticky ji využívají jak při výuce programování na stř̌ední škole. Zde využívají starší produkty firmy Borland (Borland Delphi 7), které měli s kompatibilitou výrazné problémy. Bezešvý režim, je také běžně využíván pro práci se staršími hardwarovými zařízeními, jako jsou scannery a tiskárny. V neposlední řadě je nasazení virtualizace jako nástroje pro řešení problémů s kompatibilitou zahrnuto do výuky na střední škole, konkrétně v předmětu počítačové systémy a na vysoké škole $\mathrm{v}$ předmětu operační systémy.

\section{64bitové verze systému Windows}

Při dnešním nárůstu velikosti operační paměti $\mathrm{v}$ běžně dostupných strojích. Dochází k masovému nasazování 64bitových verzí operačních systémů, Microsoft Windows nevyjímaje. Plnohodnotný běh 32bitových programů na Windows $7 \mathrm{v}$ jejich 64bitové variantě je pak řešen emulací 32bitového systému. Tyto programy se instalují do adresáré \%root\%FileSystem32, odkud jsou volány emulovaným 32bitovým režimem a tak je zajištěn jejich chod. S během 32bitových aplikací problémy obvykle nebývají. Naopak práce se staršími externími zařízeními, ke kterým nejsou $\mathrm{k}$ dispozici 64bitové ovladače, může být značně zkomplikována, nebo zcela znemožněna. Pokud není systém schopen s těmito prvky pracovat, je vhodné využít výše zmíněný Windows XP MODE, který je ze své podstaty 32bitový a umí v mnoha př́ipadech řešení poskytnout. Typickým prrípadem jsou starší zařízení na sběrnici USB.

\section{Závěr}

V mnoha článcích, diskusích a i v samotné praxi autorů se výše popsanými problémy zabývá mnoho uživatelů nových verzí operačního systému Windows 7 . V článku byla věnována pozornost ukázkám vybraných možností, jak využívat nejen didaktický a e-learningový software určený pro starší verze operačních systémů, i periferní zařízení, která mohou mít problémy s novými verzemi operačních systémů. Výše popsané metody autoři ve své pedagogické praxi aktivně využívají a pro jejich jednoduchost a efektivnost je mohou jen doporučit. Dílčí pozornost byla věnována principům těchto př́istupů na pozadí operačního systému Windows 7, tak aby uživatel měl alespoň rámcovou představu co se $v$ jeho operačním systému děje

\section{Literatura}

[1] MARC J. ROSENBERG , M. J. E-Learning: Strategies for Delivering Knowledge in the Digital Age . Columbus : McGraw-Hill, 2001. ISBN 978-0-0713-6268-9.

[2] NOVÁK BOTT; E., SIECHERT; C., STINSON C. Mistrovství v Microsoft Windows 7. Brno : Computer Press, 2010. ISBN 978-80251-2817-6.

3] TULLOCH, M., et al. Windows 7 : Resource Kit. Washington : Microsoft Press, 2010. ISBN 978-0-7356-2700-0.

[4] McLEAN, I., THOMAS, O. Configuring Windows 7 : Training Kit. Washington : Microsoft Press, 2010. ISBN 978-0-7356-2708-6. [5] Microsoft. Microsft MSDN [online]. 2009, 10.12.2010 [cit. 2011-01-19]. Volume Shadow Copy Service. Dostupné z WWW: $<$ http://msdn.microsoft.com/enus/library/bb968832(VS.85).aspx>.

[6] HIPSON , P. D. Mastering Windows XP Registry. USA : Sybex, 2002. ISBN 978-0-7821298-78.

[7] DOSTÁL, J. VYUŽITÍ VIRTUÁLNÍHO POČÍTAČE VE VZDĚLÁVÁNÍ. 1. Olomouc : Votobia Olomouc, 2008. 67 s. ISBN 978-807220-309-3.

\author{
Mgr. Josef Horálek \\ Ing. Petr Šuba \\ Univerzita Hradec Králové \\ Fakulta informatiky a managementu \\ Katedra informačních technologií \\ Hradecká 1249/6 \\ 50003 Hradec Králové \\ e-mail: josef.horalek@uhk.cz \\ e-mail: petr.suba@uhk.cz \\ www.uhk.cz
}

